\title{
Lipoprotein-Inspired Nanocarrier Composed of Folic Acid-Modified Protein and Lipids: Preparation and Evaluation of Tumor-Targeting Effect
}

This article was published in the following Dove Press journal:

International Journal of Nanomedicine

\author{
Mengmeng $\operatorname{Han}^{1,2, *}$ \\ Xiaoman $\mathrm{Ji}^{1,2, *}$ \\ Jianfei $\mathrm{Li}^{1,2, *}$ \\ Zhiming $\mathrm{Ge}^{1,2}$ \\ Bin Luo ${ }^{1,2}$ \\ Kai Zhou ${ }^{1,2}$ \\ Qianqian Wang ${ }^{1,2}$ \\ Xin Sun ${ }^{1,2}$ \\ Wei Zhang ${ }^{1,2}$ \\ Jin $\mathrm{Li}^{1,2}$
}

'Department of Pharmacy, Xuzhou Medical University, Xuzhou 221004, Jiangsu, People's Republic of China; ${ }_{2}^{2}$ Jiangsu Key Laboratory of New Drug Research and Clinical Pharmacy, Xuzhou Medical University, Xuzhou 22I004, Jiangsu, People's Republic of China

*These authors contributed equally to this work
Correspondence: Jin Li

Department of Pharmacy, Xuzhou

Medical University, 209 Tongshan Road,

Xuzhou 221004, People's Republic of

China

Tel/Fax +86 2583271293

Email lijinbaby130109@hotmail.com
Background: Reconstituted lipoproteins (rLips) based on endogenous lipid nanostructures has been increasingly regarded as an excellent and promising antitumor drug delivery. However, some problems relating to the main component, apolipoprotein, for instance, rare source, unaffordable price, and low specificity of relevant receptor expression, become chief obstacles to its broad development and application.

Purpose: The primary aim of this study is to develop biomimetic rLips by utilizing folic acid (FA)-modified bovine serum albumin (BSA) as a replacement for apolipoprotein and demonstrate its tumor targeting and antitumor efficacy.

Methods: The amino groups of BSA were covalently conjugated with FA through the amide reaction. PTX-loaded nanostructured lipid carrier (termed as P-NLC) consisting of phospholipid, cholesteryl ester, triglyceride and cholesterol was prepared by the emulsification-evaporation method and utilized as the lipid core. FA-modified BSA (FA-BSA) was characterized for the protein substitute degree and attached with NLC by incubation-insert method to form the lipoprotein-mimic nanocomplex (termed as PFB-rLips). The morphology of nanoparticles was observed under transmission electron microscopy (TEM), and the particle size and zeta potential were determined using dynamic light scattering. In vitro release behavior of PTX from PFB-rLips was investigated with the dialysis method. Hemolysis tests were conducted to evaluate the biosecurity of PFB-rLips. Cell uptake and cytotoxicity assays were performed on human hepatocytes (LO2) and human hepatoma cells (HepG2). Tumor targeting was assessed using in vivo imaging system in H22 tumor-bearing mice model. Antitumor efficacy in vivo was investigated and compared between Taxol ${ }^{\circledR}$ (paclitaxel) formulation and PTX-incorporated nanoparticles in the same tumor model.

Results: A fixed molar ratio 50:1 of FA to BSA was chosen as the optimal input ratio based on the balance between appropriate degree of protein substitution and amphiphilicity of FA-BSA. The morphology of FB-rLips exhibited as a homogeneous spherical structure featured by lipid cores surrounded with a cloudy protein shell observed under TEM. The particle size, zeta potential and encapsulation efficiency were $174.6 \pm 3.2 \mathrm{~nm},-17.26 \pm 0.9 \mathrm{mV}$ and $82.2 \pm 2.4 \%$, respectively. In vitro release behavior of PTX from PFB-rLips was slow and sustained. The uptake of FB-rLips was much higher in HepG2 cells than in LO2 cells. Furthermore, the uptake of FB-rLips was significantly higher than that of rLips without FA involved (termed as B-rLips) and NLC in HepG2 cells. Hemolysis and cytotoxicity assays showed good biocompatibility of FB-rLips. The internalization mechanism of FB-rLips mainly depended on clathrin-mediated and caveolinmediated endocytosis coupling with energy consumption, and FA receptors expressed on tumor cells played a critical role in cellular uptake process. CCK-8 studies demonstrated that PFB-rLips 
exhibited significantly better tumor killing ability than Taxol $^{\circledR}$ (paclitaxel) formulation in vitro. Moreover, FB-rLips produced more excellent tumor-targeting properties than NLC through in vivo imaging assays. On the basis of this, PTX-loaded FB-rLips also performed more remarkable anticancer activity than other therapy groups in $\mathrm{H} 22$ tumor-bearing mice.

Conclusion: FB-rLips would serve as a potential nanocarrier for improving tumor-targeting and therapeutic efficacy while reducing the side effects on normal tissues and organs.

Keywords: lipoprotein-inspired nanocarrier, BSA, folic acid, paclitaxel, tumor targeting

\section{Introduction}

Malignant tumor has become a major public health problem worldwide. However, most chemotherapeutic drugs are confronted with many defects such as negligible solubility, poor selectivity to tumor and the resulting highly toxic side effects, which can bring irreversible damage to the body while impairing antitumor efficacy. ${ }^{1,2}$ The French Rhône Poulenc's pharmaceutical company developed paclitaxel (PTX) cremophor EL injection termed as Taxol ${ }^{\circledR}$ (paclitaxel) to improve the same problems of PTX, ${ }^{3,4}$ yet it was reported to cause adverse effects such as phlebitis, toxic reactions and allergic reactions when administered systemically. 5,6 Targeting drug delivery systems based on lipoprotein-like nanostructures, mimicking the structure and physiological function of natural lipoproteins, have drawn increasing attention for their distinctive characteristics, ${ }^{7,8}$ such as their special structure, excellent biocompatibility, uniform particle size, and long circulation time.

Lipoproteins are native spherical nanoparticles, in which a nonpolar lipid core containing cholesteryl ester and triglyceride is sealed with a monolayer shell composed of phospholipid, cholesterol and apolipoproteins. ${ }^{9,10}$ Furthermore, as hydrophobic lipid carriers in blood, lipoproteins play an essential role in the transport and metabolism of cholesterol which is precisely in excessive demand during the rapid proliferation of tumor cells. ${ }^{11}$ More importantly, the recognition with the scavenger B-I receptors (SR-BI, specific receptor for apolipoprotein A-I) and low density lipoprotein receptors (LDLR, specific receptor for apolipoprotein B) overexpressed in some tumor cells offer the lipoproteins-inspired nanocarrier tumor-targeted delivery potentials.

Nevertheless, one major obstacle for developing native or synthetic lipoproteins in cancer therapy consists of the fact that the apolipoprotein and lipoprotein are difficult and complicated to acquire from human serum in large quantities, resulting in restricted supplies, high cost, and potential biosafety problems. In addition, SR-BI and LDLR mediated endocytosis is probably not a highly specific tumor-targeting delivery pathway because of the distribution in other normal tissues except for malignant tumors. To overcome the limitation that hindered the application of lipoproteins, BSA, a versatile protein with great solubility which has shown to be biocompatible, extremely robust (stable in the $\mathrm{pH}$ range of 4-9) and readily accessible, ${ }^{12}$ was chosen as an alternative for apolipoprotein to construct novel biomimetic recostituted lipoproteins (rLips). ${ }^{13,14}$ In addition, as a hydrophilic endogenous substance, BSA could prolong systemic circulation in vivo through minimizing the association with serum proteins and clearance of reticuloendothelial system (RES). ${ }^{15,16}$ Besides, BSA may target tumor cells through the GP60 receptor and SPARC-mediated endocytosis. ${ }^{17}$ Finally, many active amino groups and carboxylic groups of BSA could be decorated with a targeted ligand such as folic acid (FA) by covalent coupling.

Folate receptors (FRs), mediating the internalization of cells and uptake of FA into the cytoplasm of human eukaryotic cells, ${ }^{18,19}$ are reported highly expressed in many types of cancer cells while its distribution is limited in normal organs. $^{20}$ Eventually, a nanostructured lipid carrier (NLC) referring to the lipid composition proportion of natural lipoproteins was developed to simulate the hydrophobic core of lipoproteins. FA-modified BSA (FA-BSA) was combined with NLC by post-insert method to form the lipoproteins-mimic nanocomplex (termed as FB-rLips), which was expected to reconstruct the structure and function of the lipoproteins, to inherit the advantages and make up the shortages of natural lipoproteins, and to further improve tumor-targeting specificity through a combination of FA and BSA. ${ }^{21,22}$ The construction of the vehicle was designed as shown in Figure 1. A hydrophobic core of triglycerides and cholesteryl ester was surrounded by a shell of phospholipid monolayer and stabilized by the FA-modified BSA layer.

In this study, FA-BSA was synthesized with various degrees of substitution, and then the degree of substitution was identified with the trinitrobenzene sulfonic acid (TNBS) method. FA-BSA was incubated with NLC prepared by the emulsification-evaporation method through driving force of hydrophobic interaction to form FB-rLips. PFB-rLips were characterized in terms of size distribution, zeta potential, encapsulation efficiency (EE), morphology, biocompatibility and in vitro release of PTX from PFB-rLips. The in vitro uptake effects of FB-rLips on human hepatocytes (LO2) and 

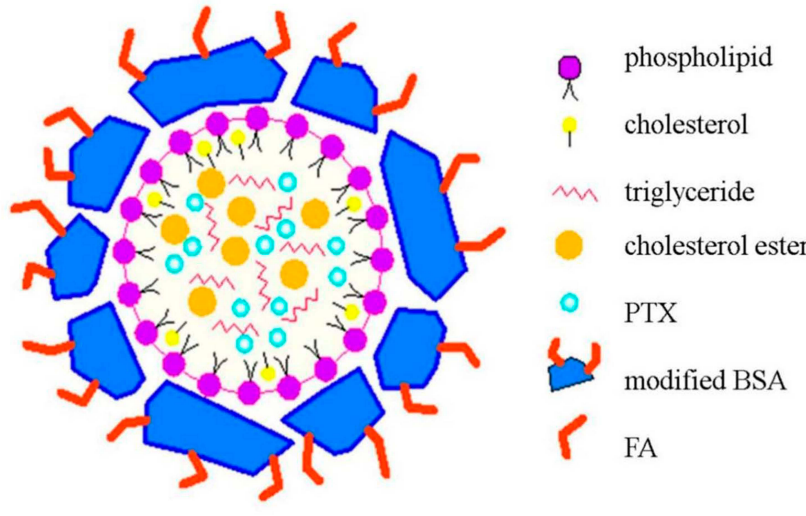

Figure I Schematic illustration of the tumor-targeting rLips based on FA-BSA.

human hepatoma cells (HepG2) were investigated. Furthermore, the cellular uptake mechanisms of FB-rLips were illuminated on HepG2 cells. In addition, cytotoxicity assays of PFB-rLips were evaluated. Finally, in vivo studies, including tumor-targeting imaging and antitumor effect were examined on $\mathrm{H} 22$ tumor-bearing mice.

\section{Materials and Methods Materials}

Phospholipid was purchased from Avanti (Shanghai, China). Cholesterol, BSA and FA were purchased from the Aladdin Biotech Co., Ltd (Shanghai, China). Triglyceride and cholesteryl ester were purchased from Tokyo Chemical Industry (Tokyo, Japan). 1-Ethyl-3-(3-dimethylamino) propylcarbodiimide hydrochloride $(\mathrm{EDC} \cdot \mathrm{HCl})$ and $\mathrm{N}$-hydroxysuccinimide (NHS) were from Bomei Biotechnology Co., Ltd (Guangzhou, China). Dialysis bag (MWCO:8000-14,000) was purchased from Shanghai Yuanye Technology Co., Ltd (Shanghai, China). Trinitrobenzene sulfonic acid was purchased from Chengdu Huayi Pharmaceutical Excipient Manufacturing Co., Ltd (Chengdu, China). Cy5 was purchased from Nanjing Bioorth BIOTECH Co., Ltd (Nanjing, China). DMEM was purchased from Jiangsu KeyGen Biotech Co., Ltd (Nanjing, China). FBS was obtained from Gibco Co. (Thermo Fisher Scientific, Waltham, MA, USA). Taxol ${ }^{\circledR}$ (paclitaxel) was purchased from the French Rhône Poulenc pharmaceutical company (Mulhouse, France).

\section{Cell Lines and Animals}

Human hepatoma cells (HepG2), human hepatocytes (LO2) and mouse hepatoma cells (H22) were purchased from the Cell Bank of Chinese Academy of Sciences (Shanghai, China). LO2, HepG2, and H22 cells were cultured in DMEM (high glucose) containing $10 \%$ inactivated FBS, $100 \mathrm{U} / \mathrm{mL}$ penicillin and $100 \mu \mathrm{g} / \mathrm{mL}$ streptomycin at $37^{\circ} \mathrm{C}$ under saturating humidity atmosphere containing $5 \% \mathrm{CO}_{2}$.

Female Kunming mice (6-8 weeks, body weight $30 \pm 5$ g) were supplied by the Experimental Animal Center of Xuzhou Medical University (Jiangsu, China). Female Kunming mice were fed a standard laboratory diet with free access to water at a controlled temperature of $20-22^{\circ} \mathrm{C}$ and relative humidity of $65 \%$ for at least five days to adapt to the new environment prior to the experiments. All animal experiments were approved by Xuzhou Medical University and performed according to the guiding principles of the Institutional Animal Care and Use Committee of Xuzhou Medical University.

\section{Synthesis and Characterization of FA-BSA}

General synthesis is shown in Figure 2. FA was covalently attached to the lysine residues of BSA to obtain the modified BSA. Carboxyl group of FA was activated by EDC and NHS (molar ratio was 1:2:1) in DMSO at $0^{\circ} \mathrm{C}$ for four hours and then overnight to obtain FA-NHSE at $20^{\circ} \mathrm{C} .{ }^{23}$ Various amounts of FA-NHSE was dissolved in $1 \mathrm{~mL}$ DMSO and then added dropwise to $2 \mathrm{~mL} \mathrm{NaHCO}_{3}$ solution containing amounts of BSA $(3.0 \% \mathrm{w} / \mathrm{v}, \mathrm{pH} 8.0)$ with agitation, in which the molar ratio of FA-NHSE to BSA varied from 40 to 90 . The reaction continuously proceeded for $10 \mathrm{~h}$ at room temperature with gentle agitation. The reacted mixture was dialyzed against distilled water at room temperature for $48 \mathrm{~h}$ and centrifuged at $10,000 \mathrm{rpm}$ for three minutes to remove extra EDC and NHS. The expected FA-BSA was obtained after lyophilization with the freeze dryer (Beijing Boyikang Laboratory Instrument Co., Ltd, Beijing, China). The above reaction conditions should be kept away from light.

In this study, the degree of substitution of BSA was determined by TNBS procedure which is a classical method for determining the substitution degree of the modified proteins. ${ }^{24}$ As follows: BSA and FA-BSA were dissolved with PBS to form a series of concentrations of samples $(0.2-1.0 \mathrm{mg} / \mathrm{mL})$, followed by addition of $0.2 \mathrm{~mL} \mathrm{NaHCO}_{3}$ solution $(4 \% \mathrm{w} / \mathrm{v}$, $\mathrm{pH} 8.5)$ and $0.2 \mathrm{~mL} \mathrm{TNBS}$ solution $(0.1 \%$, w/v). After mixture and incubation at $40^{\circ} \mathrm{C}$ for $2 \mathrm{~h}$ in dark, $0.2 \mathrm{~mL} 10 \% \mathrm{SDS}$ and $0.1 \mathrm{~mL} 1 \mathrm{M} \mathrm{HCl}$ were added and then measured using a multimode microplate reader (ELx808, BioTek Instruments Inc., Agilent Technologies, Santa Clara, CA, USA) at $415 \mathrm{~nm}$. Taking the concentration as $\mathrm{x}$-axis, the protein absorbance as the y-axis, the standard curve was drawn and then the slope of the equation was obtained according to the following formula (1) to calculate the degree of protein substitution: 

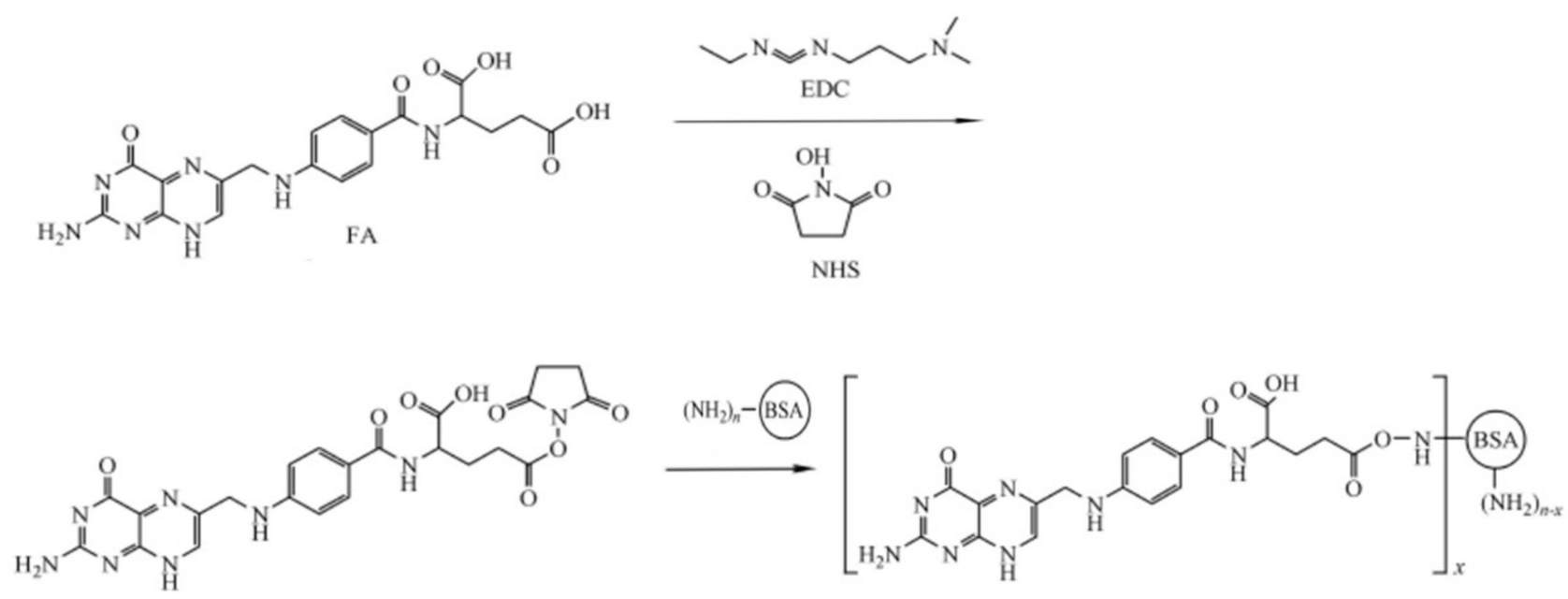

Figure 2 Graphical synthetic route of FA-BSA.

$$
D S=\left(1-\frac{K_{\text {modified BSA }}}{K_{B S A}}\right)
$$

Formula (1): where DS is the degree of substitution; $\mathrm{K}_{\mathrm{BSA}}$ and $\mathrm{K}_{\text {modified BSA }}$ are the slope rates of BSA and FA-BSA, respectively.

\section{Preparation and Characterization of FB-rLips}

The emulsification-evaporation method was utilized to prepare the hydrophobic core of rLips, and the structure was similar to NLC. NLC was composed of phospholipid, cholesteryl ester, triglyceride and cholesterol with an optimized ratio of 4:3:2:1. Briefly, phospholipid and other lipid mixtures with or without PTX were separately dissolved in 2 $\mathrm{mL}$ ethanol and $8 \mathrm{~mL}$ acetone mixture $\left(\mathrm{V}_{\text {ethanol}}\right.$ : $\left.\mathrm{V}_{\text {acetone }}=1: 4\right)$. The above two solutions were mixed fully as the organic phase, heated and kept at $65^{\circ} \mathrm{C}$ and added dropwise to $30 \mathrm{~mL}$ Tris-HCL (pH 8.0) containing $10 \mathrm{mg}$ poloxamer 188 at the same temperature. The emulsification was continued for one hour after the addition of the organic phase. Then the suspension was sonicated under $250 \mathrm{~W}$ at $0^{\circ} \mathrm{C}$ for three minutes using an ultrasonic cell shredder (Ningbo Xinzhi Biotechnology Co., Ltd, Ningbo, China), and evaporated in a rotary evaporator (Shanghai Yarong Biochemical Instrument Factory, Shanghai, China) under reduced pressure at $55^{\circ} \mathrm{C}$ to remove organic solvent and concentrated to $15 \mathrm{~mL}$. The lipid emulsion was extruded through $0.22 \mu \mathrm{m}$ to obtain PTX loaded NLC (termed as P-NLC) or NLC. Three milligrams of FA-BSA were added into $1 \mathrm{~mL} \mathrm{NLC}$ or PTX-loaded NLC to prepare FB-rLips or
PFB-rLips. The mixture suspension was incubated at $37^{\circ} \mathrm{C}$ for eight hours with gentle agitation and then the nanocomplex was extruded through $0.22 \mu \mathrm{m}$ to obtain FB-rLips or PFB-rLips. FA-BSA was substituted for unmodified BSA to prepare rLips (termed as B-rLips) following the same method.

EE was performed by microcolumn centrifugation method. ${ }^{25}$ In brief, $0.5 \mathrm{~mL}$ PFB-rLips suspension was added to the microcolumn, then centrifuged for five minutes at $1000 \mathrm{rpm}$. Repeatedly, equal volume of distilled water was used to separate PFB-rLips from free PTX under the same centrifugal conditions. Eluents were collected and demulsified by absolute ethanol. Samples after demulsification were then ultracentrifuged and the supernatant was determined. The total amount of PTX in PFBrLips suspension was measured with the same method except for separation by microcolumn. The amount of the drug entrapped in the carrier and the total drug were determined by HPLC (80D-0801, Hitachi Ltd, Tokyo, Japan) equipped with an ultraviolet (UV) detector operated at $227 \mathrm{~nm}$ and a C18 Column $(4.6 \times 250 \mathrm{~mm}, 5 \mu \mathrm{m})$. The mobile phase was methanol/water (75:25); the flow rate was kept at $1 \mathrm{~mL} / \mathrm{min}$; the column temperature was $30^{\circ} \mathrm{C}$. The EE of PTX was calculated with the following formula:

$$
E E(\%)=\frac{C}{C_{0}} \times 100 \%
$$

Formula (2): where EE is the drug encapsulation efficiency, $\mathrm{C}$ is the amount of drug encapsulated, and $\mathrm{C}_{0}$ is the total amount of drug capsuled in the carrier. 
The morphology of rLips before and after incubation with BSA and FA-BSA were observed under TEM (FEI Company, Hillsboro, OR, USA) with negative stain method. In short, NLC, B-rLips and FB-rLips were dropped onto a copper grid, then negatively stained with $1 \%$ uranyl acetate and naturally evaporated at room temperature. Particle diameter distribution and zeta potential were performed by using a NICOMP 380/ZLS zeta potential/particle size analyzer (PSS.NICOMP Particle Systems, Santa Barbara, CA, USA). Prior to each measurement, samples were dissolved with PBS (0.1 M, pH 7.4).

\section{In vitro Release Behavior}

Release behavior in vitro was performed using the dialysis method. $3 \mathrm{~mL}$ NLC, B-rLips and FB-rLips suspension loaded with PTX was transferred to dialysis bags (MW CO:8000-14,000), then placed in a beaker with $100 \mathrm{~mL}$ PBS pH7.4 containing $1 \mathrm{M}$ sodium salicylate, and gently shaken at $37^{\circ} \mathrm{C}$ and $100 \mathrm{rpm}$ in the thermostatic oscillator (Jintan District Baita Instrument Factory, Changzhou, China). In comparison, $3 \mathrm{~mL}$ PTX solution in cremophor EL and ethanol $(1: 1, \mathrm{v} / \mathrm{v})$ was carried out in the same way. Release medium $(1.0 \mathrm{~mL})$ was collected at set intervals and fresh buffer with equal volume was replenished at the same time. Samples were filtered through $0.22 \mu \mathrm{m}$ pore-size membrane filter and the continuous filtrate was served for determination by HPLC as described above.

\section{Hemolysis Tests}

Two millilters of PFB-rLips, normal saline (as negative control) and distilled water (as positive control) were mixed with $2 \mathrm{~mL}$ fresh rabbit red blood cells suspensions diluted with normal saline $(2.5 \%, \mathrm{v}: \mathrm{v})$ in different formulation concentrations of $500 \mu \mathrm{g} / \mathrm{mL}$ and $1000 \mu \mathrm{g} / \mathrm{mL}$. After incubation at $37^{\circ} \mathrm{C}$ for one hour, the hemoglobin release of different groups was observed and photographed. The suspension was centrifuged at $955 \times \mathrm{g}$ for $10 \mathrm{~min}$, and the absorbance of the supernatant was measured at $541 \mathrm{~nm}$. The hemolysis rate (HR) was calculated according to the following formula:

$$
H R(\%)=\frac{A_{1}-A_{2}}{A_{3}-A_{2}} \times 100 \%
$$

Formula (3): where HR (\%) is the hemoglobin release of different formulation, $\mathrm{A}_{1}, \mathrm{~A}_{2}$ and $\mathrm{A}_{3}$ are the absorbance of the experimental group, negative control and positive control, respectively.

\section{Cell Uptake}

To demonstrate the cellular uptake behavior in vitro, coumarin-6 (C6) was selected instead of PTX as the fluorescent dye for labeling the carriers according to the same drug encapsulation process. HepG2 and LO2 cells were seeded in 24-well plates at a density of $2.5 \times 10^{4}$ cells/well and grown for $24 \mathrm{~h}$ until $90 \%$ confluence was attained. The cells were treated with C6-loaded NLC, C6-loaded B-rLips and C6loaded FB-rLips nanosuspensions (the final concentration in the medium was $100 \mu \mathrm{g} / \mathrm{mL}$ ) and co-incubated for two hours. After washing three times with normal saline, the cells were fixed in $4 \%$ paraformaldehyde for $10 \mathrm{~min}$. The cellular uptake was qualitatively observed by inverted fluorescence microscope (Olympus Corporation, Tokyo, Japan) and quantitatively measured $\left(\lambda_{\mathrm{ex}}: 466 \mathrm{~nm}, \lambda_{\mathrm{em}}: 504 \mathrm{~nm}\right)$ with a multimode microplate reader.

To clarify the mechanism of the cellular internalization of FB-rLips, HepG2 cells were seeded in 24-well plates $\left(2.5 \times 10^{4}\right.$ cells $/$ well $)$ and incubated for $24 \mathrm{~h}$ before use. Then various endocytosis inhibitors including chlorpromazine hydrochloride (CPZ, $10 \mu \mathrm{g} / \mathrm{mL})$, sodium azide $(1 \mathrm{mg} /$ $\mathrm{mL})$, colchicine $(50 \mu \mathrm{g} / \mathrm{mL})$, bacteriocin $(6 \mu \mathrm{g} / \mathrm{mL})$ and free FA $(50 \mu \mathrm{g} / \mathrm{mL}, 100 \mu \mathrm{g} / \mathrm{mL}, 200 \mu \mathrm{g} / \mathrm{mL})$ were introduced and co-incubated with HepG2 cells for $0.5 \mathrm{~h}$, followed by addition of $100 \mu \mathrm{g} / \mathrm{mL}$ C6-loaded FB-rLips and incubation for another two hours. After that, the cells were washed three times by normal saline and determined the fluorescence intensity of $\mathrm{C} 6$ as the above method.

\section{Cytotoxicity Evaluation in vitro}

The killing effects of P-NLC, PB-rLips and PFB-rLips on HepG2 cells were estimated through CCK-8 assay. HepG2 cells were seeded in 96-well plates at a density of $1 \times 10^{4}$ cells/well for $24 \mathrm{~h}$. Then the cells were co-incubated with different PTX-loaded formulations at the final PTX concentration from 0.5 to $10 \mu \mathrm{g} / \mathrm{mL}$ for another $24 \mathrm{~h}$. Taxol ${ }^{\circledR}$ (paclitaxel) formulation was used as a control and underwent the same procedure. At given time intervals, the medium was withdrawn and $100 \mu \mathrm{L}$ CCK8 working solution was added for one-

hour incubation, and the UV absorbance was measured by a multimode microplate reader at a set wavelength of 450 $\mathrm{nm}$. Besides, the toxicities of blank NLC, B-rLips and FBrLips were also evaluated in HepG2 cells and LO2 cells at the final suspension concentration of $10 \mu \mathrm{g} / \mathrm{mL}, 500 \mu \mathrm{g} /$ $\mathrm{mL}$, and $1000 \mu \mathrm{g} / \mathrm{mL}$, respectively. Cell viability was expressed by the following formula (4): 


$$
\text { Cell viability }=\frac{O D_{1}-O D_{3}}{O D_{2}-O D_{3}} \times 100 \%
$$

Formula (4): where $\mathrm{OD}_{1}, \mathrm{OD}_{2}-\mathrm{OD}_{3}$ were the absorbance of experiment well, control well and blank well, respectively.

\section{In vivo Imaging of Tumor-Targeting Properties}

H22 tumor-bearing mice were established to assess the tumortargeting properties of FB-rLips in vivo. H22 cell suspension was injected into the abdomen cavity of Kunming mice to induce ascitic formation. And then ascites were drawn out and diluted with physiological saline to form ascites carcinoma cells at a density of $1 \times 10^{7}$ cells $/ \mathrm{mL}$. After that, ascites carcinoma cells at $0.2 \mathrm{~mL}$ per mouse were inoculated through subcutaneous injection in the back. The size of tumor (V) was measured by a fine caliper and the tumor volume was calculated according to $\mathrm{V}=\mathrm{L} \times \mathrm{W}^{2} / 2$, where $\mathrm{L}$ and $\mathrm{W}$ were the longest dimension and the shortest dimension, respectively. H22 tumor-bearing mouse model was successfully established until the tumor volume reached $350-450 \mathrm{~mm}^{3}$.

Anthocyanin Cy5 was used as the fluorescent probe to label the vector at the excitation and emission wavelengths $(630 / 700 \mathrm{~nm})$ to monitor instantly the tumor-targeting efficiency of FB-rLips in vivo. Cy5 (suifo-cyanine5 NHS ester) and FA-BSA (molar ratio was 10:1) were dissolved in 0.1 $\mathrm{mol} / \mathrm{L} \mathrm{NaHCO}_{3}$ solution, and stirred for $10 \mathrm{~h}$ at room temperature in the dark. Cy5-labeled FA-BSA was separated from free Cy5 through 24-h dialysis and collected to prepare Cy5-labeled FB-rLips. In addition, Cy5-labeled NLC was prepared by encapsulating $\mathrm{Cy} 5$ into the lipid core of NLC after removing free Cy5 through 24-h dialysis.

Eight $\mathrm{H} 22$ tumor-bearing mice were randomly divided into two groups, and received a tail intravenous injection of Cy5-labeled FB-rLips and Cy5-labeled NLC at the Cy5 dose of $0.4 \mathrm{mg} / \mathrm{kg}$. The fluorescent images were captured at 2, 4, 12, and $24 \mathrm{~h}$ post injection with the NightOWL LB 983 in vivo Image System (Berthold Technologies, Bad Wildbad, Germany). Animals were euthanized with $\mathrm{CO}_{2}$ and dissected at each observing time point after administration. Then the tumor, liver, heart, spleen, kidney, and lung were harvested, perfused with saline, and imaged using the imaging system.

\section{In vivo Antitumor Efficacy of PFB-rLips}

H22 tumor-bearing mice were randomly divided into five groups ( $\mathrm{n}=6$ per group), and intravenously injected with saline, Taxol ${ }^{\circledR}$ (paclitaxel) formulation, P-NLC, PB-rLips and PFB-rLips, separately. All group of mice were injected with above PTX formulations at PTX dose equivalent to $2 \mathrm{mg} / \mathrm{kg}$ every other day for a total of four injections. Tumor volumes were calculated as the above formula. On day nine, the mice were sacrificed to harvest subcutaneous tumors, which were photographed and weighed to calculate tumor inhibition rate (TIR) by reference to the formula (5):

$$
T I R=\frac{\left(W_{n}-W_{a}\right)}{W_{n}} \times 100 \%
$$

Formula (5): where $\mathrm{W}_{\mathrm{n}}$ was the average tumor weight of negative control group and $\mathrm{W}_{\mathrm{a}}$ was average tumor weight of administered group.

\section{Statistical Analysis}

Statistically significant differences were utilized using twotailed Student's $t$-test or one-way ANOVA (SPSS, version 16.0, SPSS Inc., Chicago, IL, USA). Statistical significance was noted as follows: ${ }^{*} p<0.05 ;{ }^{* *} p<0.01 ;{ }^{* *} p<0.001$.

\section{Results and Discussion}

\section{Synthesis and Characterization of FA-BSA}

FA-NHSE was obtained by activating the carboxyl group of FA using EDC and NHS in order to facilitate the coupling FA with the amino acid residues of BSA. This widely used method of protein esterification is mild and capable of maintaining the activity of proteins such as antibodies and enzymes. ${ }^{26,27}$ In order to obtain a suitable molecular weightmodified BSA, the molar ratio of FA to BSA was changed from 40 to 90 . The degree of substitution of FA-BSA was determined by the TNBS method. As Figure 3 illuminated, the degree of substitution increased from $25.3 \%$ to $33.2 \%$ as the molar ratio of [FA-NHSE]/[BSA] increased from 40 to 70. However, When the ratio of [FA-NHSE]/[BSA] reached 70 , there was no obvious growth trend for the substitution degree of FA-BSA, which may be ascribed to the fact that the 60 amino acid residues of BSA have been completely replaced. When the molar ratio of [FA-NHSE]/[BSA] reached 90 , the substitution degree reversely decreased to $30.5 \%$, most likely because a certain amount of FA-NHSE separated out as DMSO volatilized from reaction solvent, resulting in a decreasing combined efficiency between FANHSE and BSA. Eventually, the optimal molar ratio of FANHSE to BSA was determined to be 50 and the product possesses appropriate properties between hydrophobicity and hydrophilicity, which could be helpful to enhance the combination of FA-BSA and NLC through hydrophobic force. 


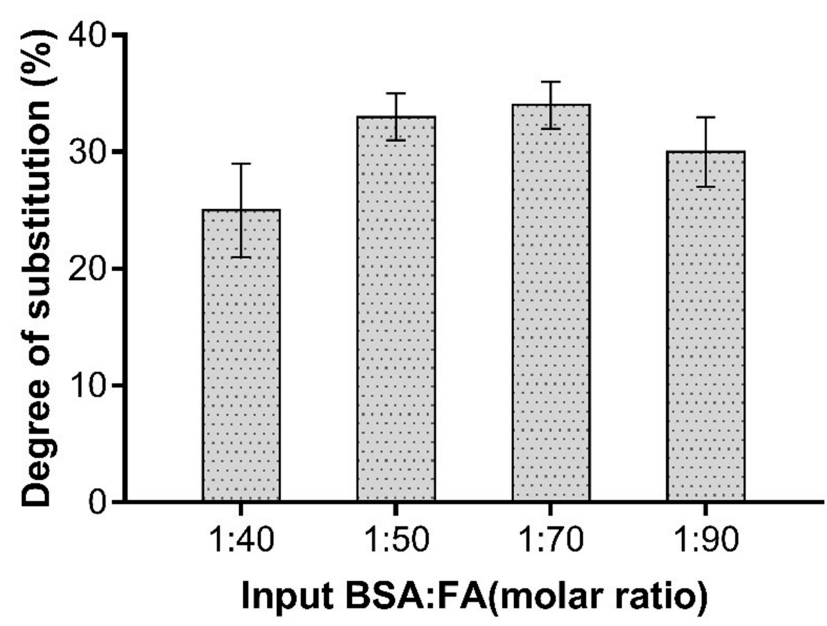

Figure 3 Substitution degree of BSA with different input ratio of BSA to FA $(n=3)$.

\section{Preparation and Characterization of FB-rLips}

NLC was prepared by emulsification-evaporation method, subsequently BSA and FA-BSA were embedded into the lipid core through hydrophobic and electrostatic force to self-assemble the reconstituted lipoprotein. ${ }^{28}$ As shown in Table 1, a significant increase of B-rLips and FB-rLips in particle size was observed from $42.8 \pm 2.7 \mathrm{~nm}$ to $138.8 \pm 3.7$ $\mathrm{nm}$ and $170.1 \pm 4.1 \mathrm{~nm}$ compared to NLC on the account of protein layer surrounding around the lipid core, which could greatly contribute to the extended blood circulation time and the consequent accumulation at tumor sites. Moreover, by the reason of the negative charge of BSA and FA-BSA in pH8.0 tris- $\mathrm{HCl}$ buffer solution, the absolute values of zeta potential of B-rLips and FB-rLips increased to $20.68 \pm 0.3$ $\mathrm{mV}$ and $18.87 \pm 0.9 \mathrm{mV}$ separately, which could prevent nanoparticles from aggregating and improve the colloidal stability of all the suspensions. ${ }^{29,30}$ After PTX encapsulation, particle size of all the vehicles got a slight increase but the change of zeta potential was not significant.

Table I Particle Size, Zeta Potential, Encapsulation Efficiency and PDI of NLC, B-rLips, FB-rLips, P-NLC, PB-rLips and PFB-rLips $(n=3)$

\begin{tabular}{|l|l|l|l|l|}
\hline Samples & Size (nm) & PDI & Zeta Potential (mV) & EE (\%) \\
\hline NLC & $42.8 \pm 2.7$ & $0.199 \pm 0.6$ & $-8.26 \pm 1.8$ & - \\
B-rLips & $138.8 \pm 3.7$ & $0.202 \pm 1.5$ & $-20.68 \pm 0.3$ & - \\
FB-rLips & $170.1 \pm 4.1$ & $0.217 \pm 0.9$ & $-18.87 \pm 0.9$ & - \\
P-NLC & $46.3 \pm 2.9$ & $0.233 \pm 1.2$ & $-7.32 \pm 1.2$ & $90.7 \pm 1.0$ \\
PB-rLips & $142.3 \pm 3.4$ & $0.186 \pm 0.8$ & $-20.34 \pm 0.8$ & $85.9 \pm 3.1$ \\
PFB- rLips & $174.6 \pm 3.2$ & $0.252 \pm 1.3$ & $-17.26 \pm 0.9$ & $82.2 \pm 2.4$ \\
\hline
\end{tabular}

As described in Table 1, the EE of PB-rLips and PFBrLips decreased slightly from $90.7 \pm 1.0 \%$ to $85.9 \pm 3.1 \%$ and $82.2 \pm 2.4 \%$, respectively, which maybe ascribed to the fact that the internal space for drug loading were partially occupied by the hydrophobic chains of BSA inserted into the lipid core.

Under TEM observation, the morphology of NLC appeared as heterogeneously distributed spherical shape, as well as the fusion and aggregation between particles (Figure 4A). The increased size after incubation with BSA and FA-BSA was also detected from TEM photographs, which indicated a favourable insertion into the lipid core. On the contrary, B-rLips (Figure 4B) and FB-rLips (Figure 4C) both presented more homogeneous spherical appearances with a distinct cloud-like shell surrounding around the lipid core after coupling with BSA and FA-BSA, which may contribute to enhance stability for B-rLips and FB-rLips through the protection of thickened hydrating protein structures against nanoparticles coalescence.

\section{In vitro Release Behavior}

Judging from the release results in Figure 5, a very fast and basically completed release of PTX was observed when comparing Taxol ${ }^{\circledR}$ (paclitaxel) formulation with other groups, the cumulative release percent of Taxol $^{\circledR}$ (paclitaxel) formulation at 2, 6, and $10 \mathrm{~h}$ were respectively $59.98 \pm 3.5 \%, 82.56 \pm 3.2 \%$, and $86.56 \pm 3.3 \%$, nevertheless at the corresponding time, the cumulative release of FBrLips containing PTX were $11.23 \pm 3.6 \%, 43.03 \% \pm 2.3 \%$, $55.19 \pm 3.3 \%$ separately and reached $70.83 \pm 1.5 \%$ at $24 \mathrm{~h}$, which meant a typically sustained release pattern, ${ }^{31}$ illustrating that the cumulative release reached to $54.46 \pm 18.4 \%$ in the earlier eight hours accompanied by a more stable release curve until $24 \mathrm{~h}$. The tendency of relative quickrelease in the earlier eight hours can be ascribed to the distribution of PTX in the shell or surface of rLips and partial amount of dissolved drug in the aqueous phase with the aid of surfactant, while a sustained release in the rest of the time mainly depended on the PTX package in the lipid core of rLips. Besides, B-rLips exhibited similar release feature with FB-rLips, and both of them have a slower release rate than NLC group, which could be attributed to some extent to the delay effect of protein shell distribution on the surface of FB-rLips and B-rLips.

\section{Hemolysis Tests}

In view of the potential use for systemic administration, hemolysis of PFB-rLips was conducted to investigate its 

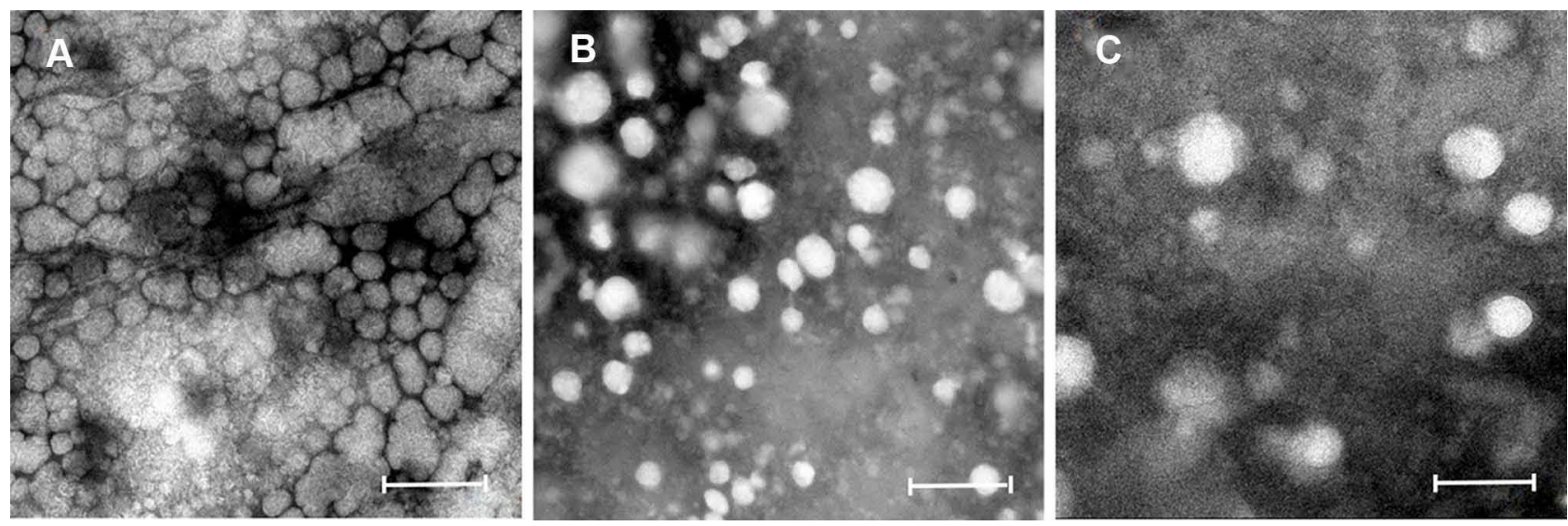

Figure 4 TEM images of NLC (A), B-rLips (B) and FB-rLips (C). The bar of B is $500 \mathrm{~nm}$. The bar of A and C are $200 \mathrm{~nm}$.

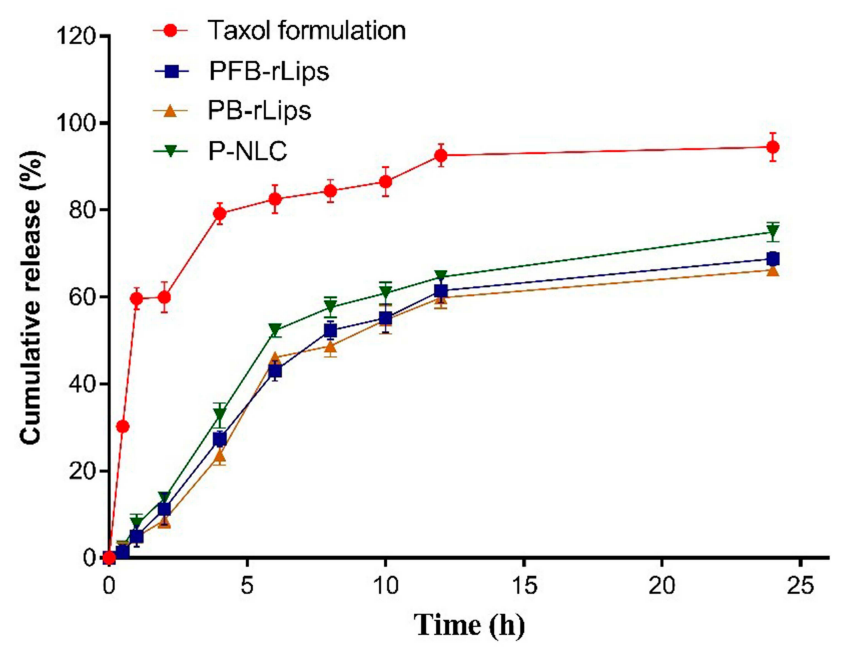

Figure 5 In vitro cumulative release of PTX from P-NLC, P-rLips, PFB-rLips and Taxol $^{\circledR}$ (paclitaxel) formulations $(n=3)$.

biosafety. As shown in Figure 6, PFB-rLips at the concentrations of $500 \mu \mathrm{g} / \mathrm{mL}(\mathrm{C}, \mathrm{D})$ and $1000 \mu \mathrm{g} / \mathrm{mL}$ (E, F) were found not to cause hemolysis compared to negative control (A, B). Furthermore, HR of PFB-rLips at the corresponding concentrations were merely $0.59 \pm 0.03 \%$ and 1.40 $\pm 0.02 \%$. Combining the above results, it can be inferred that PFB-rLips possesses good biocompatibility and low antigenicity, which could be regarded as a reliable biomimetic nanocarrier for further studies.

\section{Cell Uptake}

Human hepatoma cells (HepG2 cells, FRs-positive) and human hepatocytes (LO2 cells, FRs-negative) were chosen to illuminate the targeting effect of BSA or/and FA groups attached to the surface of rLips. By contrast with NLC, an enhanced fluorescent intensity was observed in HepG2 cells incubated with B-rLips (Figure 7A), which exactly confirmed the tumor-targeting property of BSA mainly through the approach of GP60 and SPAR. ${ }^{32}$ As illustrated in Figure 7A, the intracellular fluorescent intensity of HepG2 cells treated with FB-rLips was remarkably higher than that in LO2 cells, and the uptake of FB-rLips by HepG2 cells was around 1.41-fold as much as that of B-rLips (Figure 7B). Nevertheless, there was no remarkable difference between the uptake of FB-rLips and B-rLips by LO2 cells (Figure 7B). It can be inferred that the modification of FA could further increase the tumor cell targeting selectivity on the basis of promoting endocytic uptake of BSA, which made FB-rLips present a dualtargeting characteristic through a combination of BSA and FA.

The mechanism of the cellular internalization of nanoparticles is mainly divided into four types: clathrin-dependent endocytosis, caveolin-dependent endocytosis, giant pinoside, clathrin and caveolin-independent endocytosis. To clarify the uptake mechanism of FB-rLips, four endocytosis inhibitors including CPZ, sodium azide, colchicine, bacteriocin and free FA were selected and their respective functions are as follows: sodium azide inhibits ATPase, CPZ blocks clathrin, bacteriocin inhibits caveolin, and colchicine inhibits tubulin and blocks the giant pinocytosis. ${ }^{33}$ As seen in Figure $7 \mathrm{C}$, the internalization of FB-rLips was significantly inhibited when HepG2 cells were pre-incubated with CPZ (approximate $47.49 \pm 0.35 \%$ decrease), bacteriocin (approximate 45.17 $\pm 1.68 \%$ decrease), and sodium azide (approximate 67.55 $\pm 2.32 \%$ decrease), suggesting that the uptake of FB-rLips by HepG2 mainly relied on the clathrin-mediated endocytosis and caveolin-mediated endocytosis coupling with energy consumption. Furthermore, the cells were pretreated with FA in serial concentrations $(50-200 \mu \mathrm{g} / \mathrm{mL})$, and subsequent decreases of cellular internalization were detected and the 


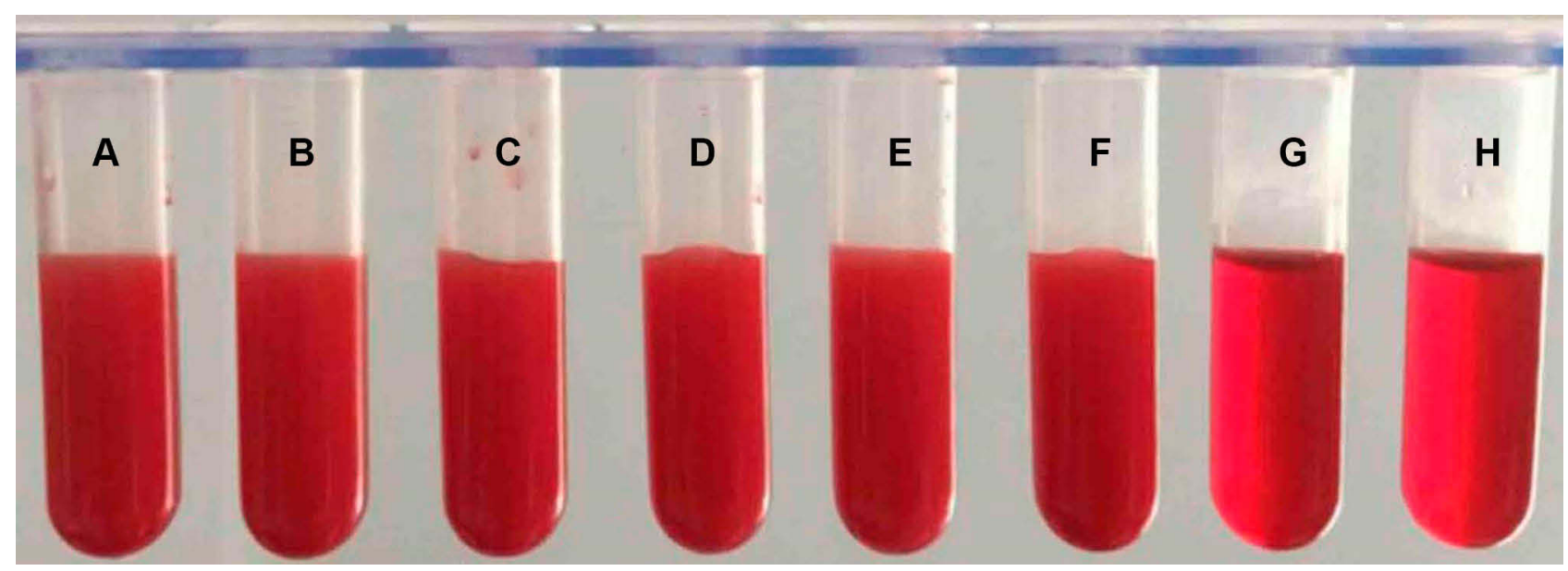

Figure 6 Rabbit red blood cells incubated with different concentrations of PFB-rLips, normal saline and distilled water at $37^{\circ} \mathrm{C}$ for I h. Tube (A,B) normal saline (negative control); tube (C, D) formulations of $500 \mu \mathrm{g} / \mathrm{mL}$; tube (E, F) formulations of $1000 \mu \mathrm{g} / \mathrm{mL}$; tube (G, H) distilled water (positive control).

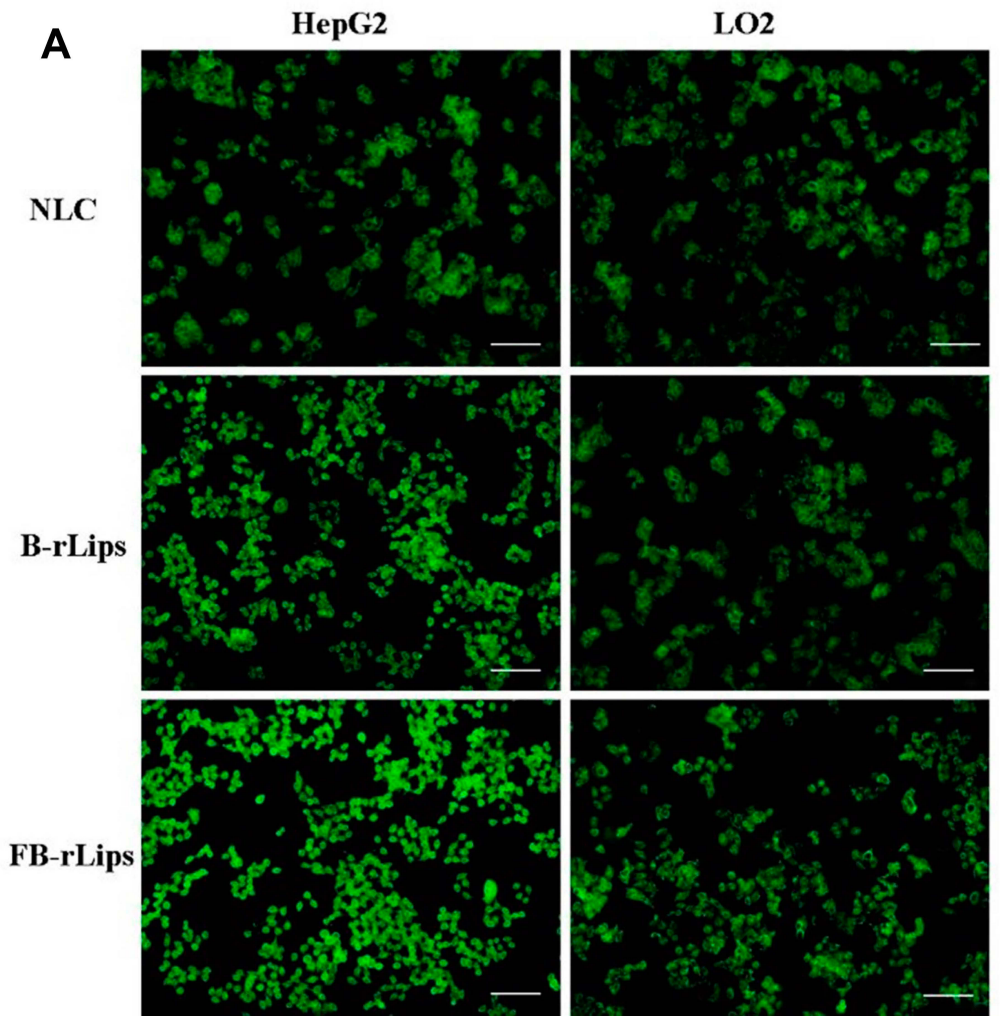

\section{B}

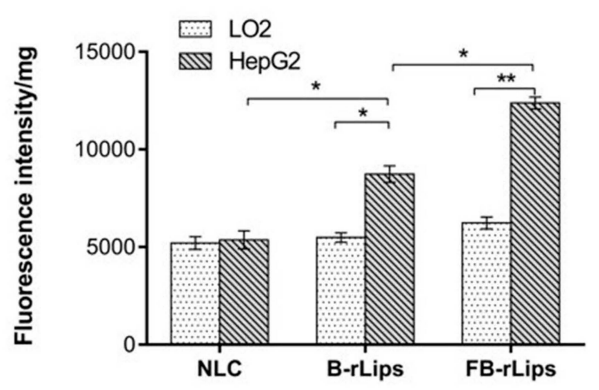

C

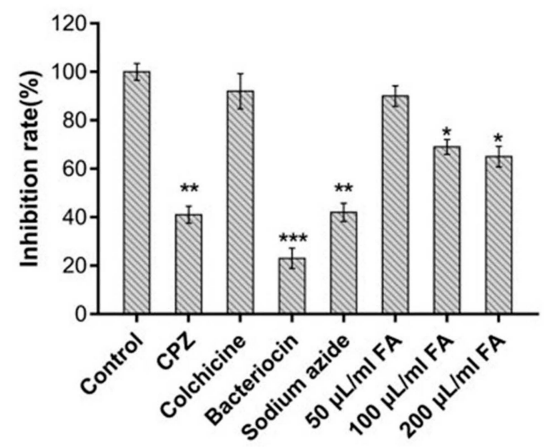

Figure 7 (A) Images of HepG2 and LO2 cells treated with NLC, B-rLips, FB-rLips, respectively. The bar was $100 \mu \mathrm{m}$. (B) Uptake of NLC, B-rLips, FB-rLips in HepG2 and LO2 cells observed qualitatively by a multimode microplate reader $(n=5),{ }^{*} p<0.05, * * p<0.01$. (C) The effects of various inhibitors and serial concentrations of FA on the endocytosis of FB- rLips into HepG2 cells $(n=5)$. ${ }^{*} p<0.05, * *_{p}<0.01$, $* * * p<0.001$ compared to control group.

relative uptake efficiency decreased to about $68 \%$ and $53 \%$. These results demonstrated that FB-rLips took advantage of not only clathrin-mediated but also caveolae-mediated endocytosis ways inside HepG2 cells, and FRs expressed on the surface of tumor cells played a significant role in this endocytosis process. 


\section{Cytotoxicity Evaluation in vitro}

The killing effect on HepG2 cells were estimated through CCK-8 assay to evaluate the therapeutic effects of P-NLC, PB-rLips and PFB-rLips. As described in Figure 8A, all PTX formulations effectively reduced the tumor cell viability and the killing effect enhanced following the increasing PTX concentrations. PFB-rLips exhibited dramatically better antitumor efficiency than PB-rLips, P-NLC and Taxol ${ }^{\circledR}$ (paclitaxel) formulation at almost all PTX concentrations due to the introduction of FA groups on the basis of BSA, and P-NLC had similar antitumor activity with Taxol ${ }^{\circledR}$ (paclitaxel) formulation. For instance, the tumor cell viability was approximately $50 \%$ and $44 \%$ at a PTX concentration of $5.0 \mu \mathrm{g} / \mathrm{mL}$ as result of the treatment with PB-rLips and PFB-rLips, while P-NLC and $\mathrm{Taxol}^{\circledR}$ (paclitaxel) exhibited about $80 \%$ and $78 \%$ tumor cell viability at the same drug concentration.
The cytotoxicity of blank NLC, B-rLips and FB-rLips was also assessed in both $\mathrm{LO} 2$ cells and $\mathrm{HepG} 2$ cells (Figure 8B, C). The cell viability was more than $80 \%$ after $24 \mathrm{~h}$ of incubation with blank NLC, B-rLips and FBrLips at different concentrations of 10,500 , and $1000 \mu \mathrm{g} /$ $\mathrm{mL}$, indicating a potential biological security which may have originated from natural sources of components assembling the lipid core and surrounding BSA.

\section{Tumor-Targeting Properties Evaluated by Imaging}

Live imaging of $\mathrm{H} 22$ tumor-bearing mice injected with Cy5labeled FB-rLips and Cy5-labeled NLC via the tail vein was performed to observe the distribution of two types of nanoparticles. Figure 9 displayed the fluorescent signals localized at the tumor site of the mice and the removed organs and tumors. From 2 to $12 \mathrm{~h}$, the fluorescence of the tumor site in
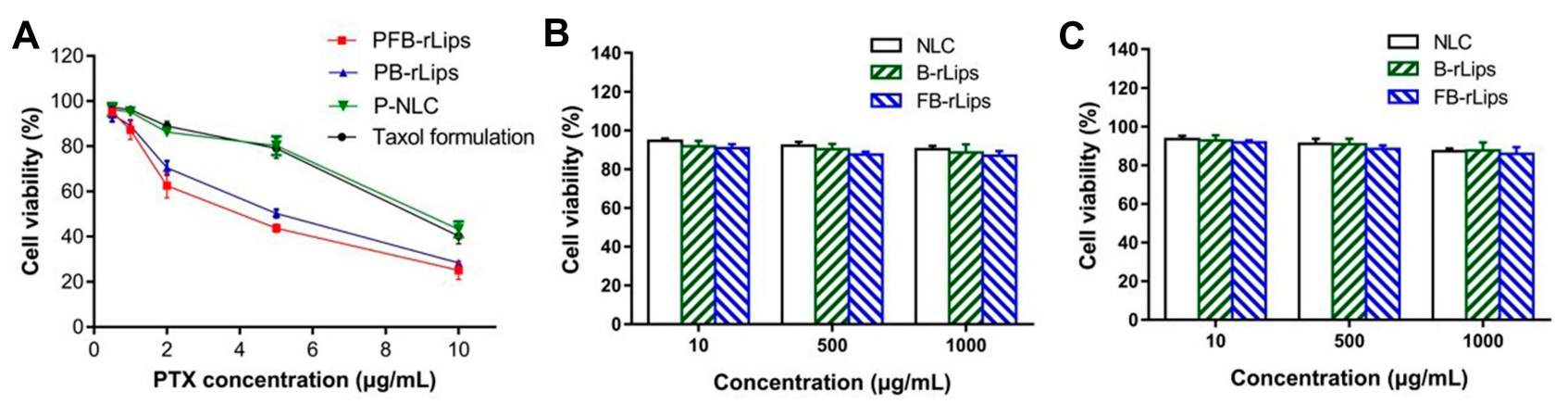

Figure 8 (A) In vitro killing ability of P-NLC, PB-rLips, PFB-rLips and Taxol ${ }^{\circledR}$ (paclitaxel) formulation against HepG2 cells, respectively ( $\mathrm{n}=5$ ). (B, C) In vitro cytotoxicity of blank NLC, B-rLips and FB-rLips against HepG2 and LO2 cells, respectively $(n=5)$.

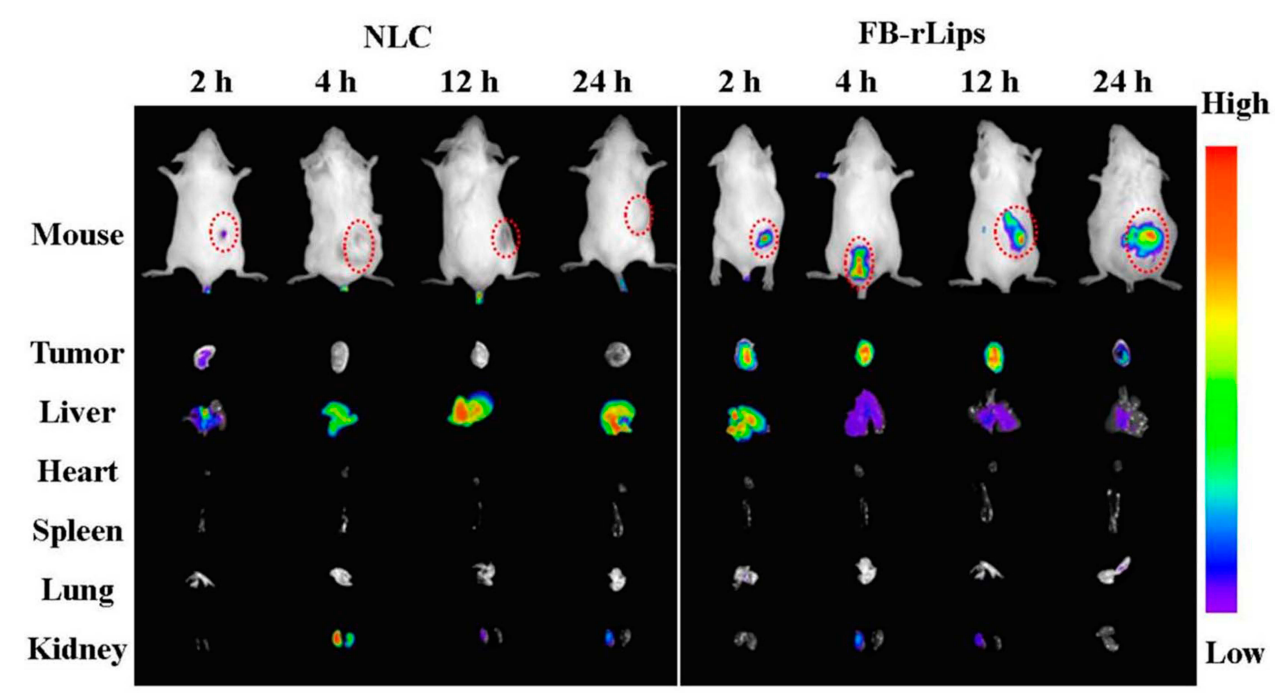

Figure 9 In vivo imaging of $\mathrm{H} 22$ tumor-bearing mice at 2, 4, I2, and $24 \mathrm{~h}$ after intravenous administration of Cy5-labeled NLC and Cy5-labeled FB-rLips and ex vivo imaging of tumor and normal organs collected from mice at each observing time point. 
Cy5-labeled NLC group mice (Figure 9) was always slightly weak with respect to the strong fluorescent signals focused on the liver, and the fluorescence intensity attenuated gradually with the extension of time, followed by a subsequent nearly disappearing in $24 \mathrm{~h}$. The fluorescence intensity in those tumor sites injected with Cy5-labeled FB-rLips at different time points was stronger than those injected with Cy5-labeled NLC (Figure 9). In addition, tumor sites in the Cy5-labeled FB-rLips group exhibited stronger fluorescent signals at designated times relative to other organs, and the intensity of fluorescence at tumor sites lasted up to a certain extent $24 \mathrm{~h}$ after injection, which could be attributed to the rapid targeting and persistent residence in tumors accomplished by FB-rLips. As a consequence, the combination of BSA and FA effectively prolonged the residence time of antitumor drug in blood and tumors, increased the chance of distribution to tumor tissue and reduced the irrelevant involvement to other parts of the body.

\section{In vivo Antitumor Effect}

H22 tumor-bearing mice were used to evaluate the in vivo antitumor effect of PFB-rLips. As shown in Figure 10A, the growth of the tumor was significantly inhibited after the mice were continually injected with different PTX formulations including Taxol ${ }^{\circledR}$ (paclitaxel) formulation, P-NLC, PB-rLips and PFB-rLips compared with saline as a negative control. PFB-rLips exhibited a stronger tumor inhibition capacity than P-NLC and PB-rLips, which was ascribed to a combination of $\mathrm{FA}$ and BSA-mediated targeting. Moreover, seen from Figure 10B, P-NLC and PB-rLips showed an ascended TIR due to the properties of BSA such as prolonged systemic circulation by minimizing clearance of RES and specific positive tumor targeting through GP60 receptor and SPARC-mediated endocytosis, compared with the Taxol ${ }^{\circledR}$ (paclitaxel) formulation group. Foremostly, PFBrLips performed the highest TIR (89.9\%) in all experimental groups, which keep a close relationship with the apparent targeting effect in vivo on account of the introduction of FA on the basis of BSA. These results are in accordance with in vitro cell killing evaluation data (Figure 8A), confirming that PFB-rLips induced higher anticancer activity both in vitro and in vivo.

\section{Conclusions}

In summary, a PTX-loaded nanostructure, PFB-rLips, that with FA-BSA, was designed as a versatile nanomedicine by facilitating tumor-targeting and improving target efficiency. Both in vitro and in vivo experiments were conducted to demonstrate the possibility and outstanding diseasemodifying effect of this biomimetic nanomedicine. According to the above results, PFB-rLips was endowed with lipoprotein-like structure, favorable particle size, zeta potential, PTX EE\% and desirable release behavior. Furthermore, it was found that the uptake of FB-rLips was much higher in HepG2 cells than LO2 cells and was significantly higher than that of rLips in the absence of FA. More importantly, FB-rLips exhibited a rapid targeting and persistent accumulation within the tumor site while it was nearly invisible in major organs under in vivo imaging observation. The results of antitumor experiment on $\mathrm{H} 22$ tumor-bearing
A

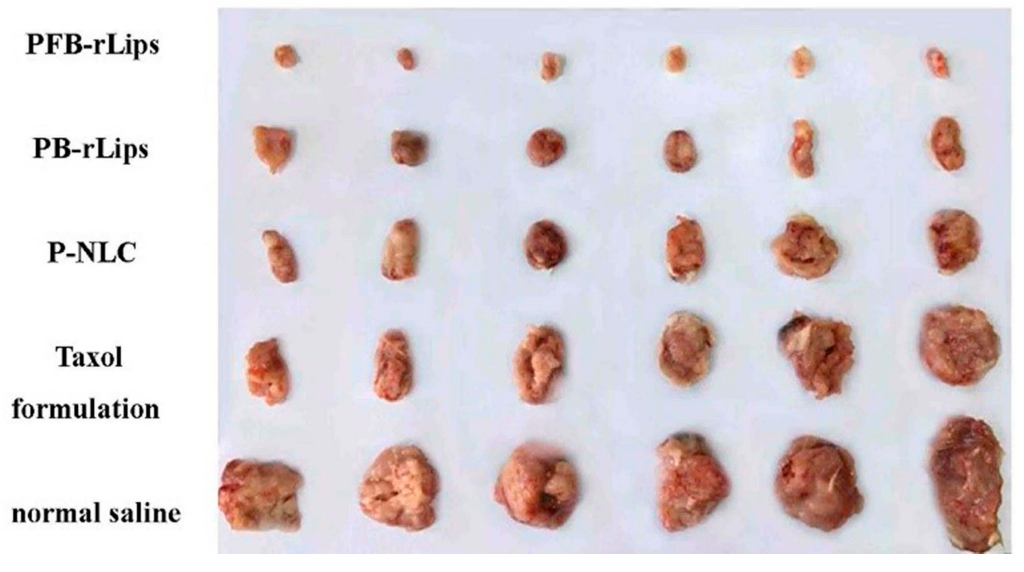

B

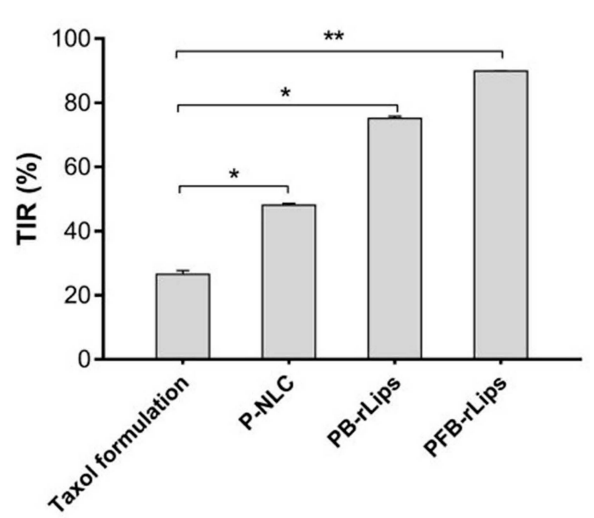

Figure 10 (A) The dissected tumors after treatment with different PTX formulations including PFB-rLips, PB-rLips, P-NLC, Taxol ${ }^{\circledR}$ (paclitaxel) formulation and normal saline on day eight. (B) The tumor inhibition rates after treatment with paclitaxel formulation, P-NLC, PB-rLips and PFB-rLips on day eight, respectively ( $=6$ ). ${ }^{*}<<0.05$, $*^{*} p<0.01$. 
mice further manifested the excellent tumor-targeting efficacy of PFB-rLips. These findings provided evidence of a biomimetic nanomedicine targeting to tumor, releasing drugs, and exerting anticancer activity, indicating that the lipoprotein-like nanocarrier could serve as an available and flexible drug delivery system for targeting anticancer treatment.

\section{Acknowledgments}

This study is financially supported by the National Science Foundation Grant of China (No. 81502997) and Jiangsu Government Scholarship for Overseas Studies.

\section{Disclosure}

The authors report no conflicts of interest in this work.

\section{References}

1. Arii S, Yamaoka Y, Futagawa S, et al. Results of surgical and nonsurgical treatment for small-sized hepatocellular carcinomas: a retrospective and nationwide survey in Japan. Hepatology. 2010;32(6):1224-1229. doi:10.1053/jhep.2000.20456

2. Eliezer M, Tran H, Inagaki A, et al. Clinical and radiological characteristics of malignant tumors located to the cerebellopontine angle and/or internal acoustic meatus. Otol Neurotol. 2019. doi:10.1097/ MAO.0000000000002360

3. Huizing MT, Rosing H, Koopmans FP, Beijnen JH. Influence of Cremophor EL on the quantification of paclitaxel in plasma using high-performance liquid chromatography with solid-phase extraction as sample pretreatment. J Chromatogr B Biomed Sci Appl. 1998;709 (1):161-165. doi:10.1016/S0378-4347(98)00043-7

4. Cao YJ, Zhou Y, Zhuang Q, et al. Anti-tumor effect of RGD modified PTX loaded liposome on prostatic cancer. Int J Clin Exp Med. 2015;8 (8):12182-12191.

5. Singla AK, Garg A, Aggarwal D. Paclitaxel and its formulations. Int J Pharm. 2002;235(1):179-192. doi:10.1016/S0378-5173(01)00986-3

6. Yang $\mathrm{CH}$, Horwitz SB. Taxol ${ }^{\circledR}$ : the first microtubule stabilizing agent. Int J Mol Sci. 2017;18:8. doi:10.3390/ijms18081733

7. Mehrdad H, Mahshid F, Abdolhossein Z. Lipoproteins: from physiological roles to drug delivery potentials. Crit Rev Ther Drug Carrier Syst. 2006;23(6):497. doi:10.1615/CritRevTherDrugCarrierSyst.v23.i6.20

8. Céline V, Martinez LO, Ferrières J, et al. Targeting high-density lipoproteins: update on a promising therapy. Arch Cardiovasc Dis. 2013;106(11):601-611. doi:10.1016/j.acvd.2013.06.052

9. Wasan KM, Brocks DR, Lee SD, Kristina SB, Thornton SJ. Impact of lipoproteins on the biological activity and disposition of hydrophobic drugs: implications for drug discovery. Nat Rev Drug Discov. 2008;7 (1):84. doi:10.1038/nrd2353

10. Rensen PC, de Vrueh RLA, Kuiper J, et al. Recombinant lipoproteins: lipoprotein-like lipid particles for drug targeting. Adv Drug Deliv Rev. 2001;47(2-3):251-276. doi:10.1016/S0169-409X(01) 00109-0

11. Zhang WL, et al. Structure and remodeling behavior of drug-loaded high density lipoproteins and their atherosclerotic plaque targeting mechanism in foam cell model. Int J Pharmaceutics. 2011;419(1-2):314-321.

12. Zhan Y, Min Y, Zhibao Z, Ge H, Qingqing X. Bovine serum albumin nanoparticles as controlled release carrier for local drug delivery to the inner ear. Nanoscale Res Lett. 2014;9(1):343. doi:10.1186/1556-276X9-343
13. Silva-Lopez EI, Edens LE, Barden AO, Keller DJ, Brozik JA. Conditions for liposome adsorption and bilayer formation on BSA passivated solid supports. Chem Phys Lipids. 2014;183:91-99. doi:10.1016/j.chemphyslip.2014.06.002

14. Rui Y, et al. Preparation of folic acid-conjugated, doxorubicin-loaded, magnetic bovine serum albumin nanospheres and their antitumor effects in vitro and in vivo. Int J Nanomedicine. 4231.

15. Furumoto K, Yokoe J, Ogawara K, et al. Effect of coupling of albumin onto surface of PEG liposome on its in vivo disposition. Int J Pharm. 2007;329(1-2):110-116. doi:10.1016/j.ijpharm.2006.08.026

16. Yokoe JI, Sakuragi S, Yamamoto K, et al. Albumin-conjugated PEG liposome enhances tumor distribution of liposomal doxorubicin in rats. Int J Pharm. 2008;353(1):28-34. doi:10.1016/j.ijpharm.2007.11.008

17. Schnitzer JE. gp60 is an albumin-binding glycoprotein expressed by continuous endothelium involved in albumin transcytosis. Am J Physiol. 1992;262(1 Pt 2):H246.

18. Parker N, Turk MJ, Westrick E, et al. Folate receptor expression in carcinomas and normal tissues determined by a quantitative radioligand binding assay. Anal Biochem. 2005;338(2):284-293. doi:10.1016/j. ab.2004.12.026

19. Assaraf YG, Leamon CP, Reddy JA. The folate receptor as a rational therapeutic target for personalized cancer treatment. Drug Resist Updates. 2014;17(4-6):89-95. doi:10.1016/j.drup.2014.10.002

20. Pillai JJ, Anto RJ, Chithralekha DN, Narayanan A. Folic acid conjugated cross-linked acrylic polymer (FA-CLAP) hydrogel for site specific delivery of hydrophobic drugs to cancer cells. J Nanobiotechnology. 2014;12(1):25. doi:10.1186/1477-3155-12-25

21. Ma N, Liu J, He W, Li Z, Garg S. Folic acid-grafted bovine serum albumin decorated graphene oxide: an efficient drug carrier for targeted cancer therapy. J Colloid Interface Sci. 2016;490:598-607. doi:10.1016/j.jcis.2016.11.097

22. $\mathrm{Zu}$. Preparation, characterization, and in vitro targeted delivery of folate-decorated paclitaxel-loaded bovine serum albumin nanoparticles. Int J Nanomedicine. 2010;669. doi:10.2147/IJN.S12918

23. Lee RJ, Low PS. Delivery of liposomes into cultured KB cells via folate receptor-mediated endocytosis. J Biol Chem. 1994;269 (5):3198-3204.

24. Laccotripe M, Makrides SC, Jonas A, Zannis VI. The carboxyl-terminal hydrophobic residues of apolipoprotein A-I affect its rate of phospholipid binding and its association with high density lipoprotein. J Biol Chem. 1997;272(28):17511-17522. doi:10.1074/ jbc.272.28.17511

25. Maghraby GMME, Williams AC, Barry BW. Skin delivery of 5-fluorouracil from ultradeformable and standard liposomes in-vitro. J Pharm Pharmacol. 2010;53(8):1069-1077. doi:10.1211/0022357011776450

26. Hawkins MJ, Patrick SS, Neil D. Protein nanoparticles as drug carriers in clinical medicine. Adv Drug Del Rev. 2008;60 (8):876-885. doi:10.1016/j.addr.2007.08.044

27. Rafols C, Amezqueta S, Fuguet E, Bosch E. Molecular interactions between warfarin and human (HSA) or bovine (BSA) serum albumin evaluated by isothermal titration calorimetry (ITC), fluorescence spectrometry (FS) and frontal analysis capillary electrophoresis (FA/CE). J Pharm Biomed Anal. 2018;150:452-459. doi:10.1016/j. jpba.2017.12.008

28. Tang, Tang D-W, Yu S-H, et al. Characterization of tea catechins-loaded nanoparticles prepared from;chitosan and an edible polypeptide. Food Hydrocoll. 2013;30(1):33-41. doi:10.1016/j. foodhyd.2012.04.014

29. Song Z, Feng R, Sun M, et al. Curcumin-loaded PLGA-PEG-PLGA triblock copolymeric micelles: preparation, pharmacokinetics and distribution in vivo. J Colloid Interface Sci. 2011;354(1):116-123. doi:10.1016/j.jcis.2010.10.024

30. Wang Y, Li P, Kong L. Chitosan-modified PLGA nanoparticles with versatile surface for improved drug delivery. AAPS PharmSciTech. 2013;14(2):585-592. doi:10.1208/s12249-013-9943-3 
31. Guo Y, Zhang Y, Li J, et al. Cell microenvironment-controlled antitumor drug releasing-nanomicelles for GLUT1-targeting hepatocellular carcinoma therapy. ACS Appl Mater Interfaces. 2015;7(9):5444. doi:10.1021/am5091462

32. Zhao D, Zhao X, Zu Y, et al. Preparation, characterization, and in vitro targeted delivery of folate-decorated paclitaxel-loaded bovine serum albumin nanoparticles. Int J Nanomedicine. 2010;5(default):669-677. doi:10.2147/ijn.s12918
33. Hillaireau H, Couvreur P. Nanocarriers' entry into the cell: relevance to drug delivery. Cell Mol Life Sci. 2009;66(17):2873-2896. doi:10.1007/s00018-009-0053-z
International Journal of Nanomedicine

\section{Publish your work in this journal}

The International Journal of Nanomedicine is an international, peerreviewed journal focusing on the application of nanotechnology in diagnostics, therapeutics, and drug delivery systems throughout the biomedical field. This journal is indexed on PubMed Central, MedLine, CAS, SciSearch ${ }^{\prime \prime}$, Current Contents $/$ /Clinical Medicine,
Journal Citation Reports/Science Edition, EMBase, Scopus and the Elsevier Bibliographic databases. The manuscript management system is completely online and includes a very quick and fair peer-review system, which is all easy to use. Visit http://www.dovepress.com/ testimonials.php to read real quotes from published authors. 